Historia Slavorum Occidentis

2020, nr 2 (25)

ISSN 2084-1213

DOI: $10.15804 /$ hso200202

\author{
Hanna KóčKa-Krenz (Poznań)
}

ORCID: 0000-0002-2082-8177

\title{
A goldsmith's workshop in the Poznań stronghold as an indication of cultural contacts between the Piast and the Přemyslid dynasties*
}

Słowa kluczowe: wczesne średniowiecze, gród w Poznaniu, rezydencja książęca, pracownia złotnicza, kontakty kulturowe, Piastowie, Przemyślidzi

Keywords: Early Middle Ages, the Poznań stronghold, ducal residence, goldsmith's workshop, cultural contacts, the Piasts, the Přemyslid dynasty

Abstract: This paper gives details on a feature uncovered during archaeological research in Ostrów Tumski in Poznań, which yielded crucibles with particles of gold, fragments of gold foil, filigree, rivets, semi-finished products and finished products and beads from decorative stones. The feature was identified as a goldsmith's workshop and attempts were made to determine the origin of the raw materials and where the artisans came from.

Archaeological research into St. Mary's Church in Ostrów Tumski in Poznań, undertaken after 53 years, have led to discovering a palas ${ }^{1}$ as well as remains of a workshop

The work is financed as part of a programme of the Ministry of Science and Higher Education, “The National Programme for the Development of Humanities” in 2014-2020, project no. 0040/ NPRH3/H11/82/2014.

1 H. Kóčka-Krenz, Początki monumentalnej architektury świeckiej na grodzie poznańskim, 
operating in the ducal part of the Poznan stronghold ${ }^{2}$. Nearly the entire outline of the workshop has been uncovered with the exception of the southern edge hidden under a fence separating premises at 9 Ostrów Tumski and 10 Ostrów Tumski³ The subsequent construction works including demolition of the stone palas partly destroyed the object in questions. Nevertheless, the workshop has been examined well enough to define its dimensions and stratigraphic position with a degree of uncertainty while the materials in question shed light on the nature of the craft practised there.

The goldsmith's workshop was located in a building to the west of the ruler's residence. When the palas was demolished, only the lower part of the foundation survived and on that place a regular pile of rock material was placed, obtained from a demolished wall. The in situ arrangement ${ }^{4}$ was also covered with a fragment of the workshop's interior. The relicts were uncovered at 1.65-1.75 m below the contemporary usage surface in the form of a cluster of burnt down wooden elements and a layer of light grey ash. This layer was laid in an uneven strip of $60 \mathrm{~cm}$, about $40 \mathrm{~cm}$ higher than the place where the palas' foundation morphed into a part of its wall, marking the floor space from the 2 nd half of the $10^{\text {th }}$ century. ${ }^{5}$ On this level, the outline of the workshop can be recreated; it was built on a rectangle on a north-south axis. It was $3 \mathrm{~m}$ wide and nearly $5 \mathrm{~m}$ long, closing up an interior of approximately $15 \mathrm{~m}^{2}$. The western wall of the building was most probably adjacent to the wall of the palas because along the relics of its foundation ran an irregular, thick patch of gypsum underlayment with prints of the ends of two laths (?) $30 \mathrm{~cm}$ broad and $10 \mathrm{~cm}$ thick; outside the underlayment was a negative of a pole surrounded by stones. On the other side of the underlayment, half-way through the workshop's width, negatives of two solid poles have survived, each with a diameter of $30 \mathrm{~cm}$ and stabilised with stones. The first one, sunk $60 \mathrm{~cm}$ deep, was placed next to the building's northern wall. The other one, sunk $30 \mathrm{~cm}$ deep, was located in the middle of the work-

[in:] Początki architektury monumentalnej w Polsce, eds. T. Janiak, D. Stryniak, Gniezno 2004, pp. 71-84.

2 This paper is an updated version of H. Kóčka-Krenz's article Pracownia złotnicza na poznańskim grodzie, published in: Świat Stowian wczesnego średniowiecza, eds. M. Dworaczyk, A.B. Kowalska, S. Moździoch and M. Rębkowski, Szczecin-Wrocław 2006, pp. 257-272.

3 In this place, an electric box was also placed thus excluding the area from field research.

4 It is a type of a buttress reinforcing a corner of the palace building, probably reduced by a single room after some time of using thereof.

5 H. Kóčka-Krenz, Początki monumentalnej architektury, p. 82. 
shop; the distance between them amounted to $1.85 \mathrm{~m}$. The western part of the structure was filled with a layer of russet dirt with particles of burnt wood with a dark grey rim on the edge. At a distance of $80 \mathrm{~cm}$ from it and $1.60 \mathrm{~m}$ from the northern wall was a negative of a quadrangular pole measuring $10 \times 20 \mathrm{~cm}$. In the south - eastern part of the building remained elements of a charred wooden structure on a layer of ash; the materials gathered there indicate their function. In this part, remains of two stakes were identified; they had been dug at the same depth - one next to the southern profile, the other one to the north of it, at a distance of $90 \mathrm{~cm}^{6}$.

The stratigraphic arrangement on the level of the building's relics (thickness of approximately $35 \mathrm{~cm}$ ) indicates how the interior was planned. The bottom remained basically on the same level, slightly yielding toward the palas' foundation. This should be attributed to the pressure exerted by a heap of rock material. Along the western wall, a distinct depression has been identified, narrowing downwards with a bottom located $70 \mathrm{~cm}$ below the remaining part of the structure. The opposite, eastern edge of the depression was not very distinct but rather outlined by a pole and a layer of ash in the ceiling. Materials collected in this layer are evidence of the building's function: crucibles, goldsmith raw materials, gems, glass beads and bronze plates.

Six fragments of clay crucibles were excavated from the building's fill. Five of them bear traces of high temperatures at work; as a result, an admixture of quartz in the ceramic mass on the outer surface was glazed while the walls turned ashgrey with black accents. These thermo-chemical changes take place in ceramic when the temperature reaches $850^{\circ} \mathrm{C}$ up to $900^{\circ} \mathrm{C}$; at the temperature of approximately $1000^{\circ} \mathrm{C}$ the glazing stage starts thus building up a utensil's mechanical resistance ${ }^{7}$. The fragment with the maintained part of the edge suggests that the crucibles with walls $0.6 \mathrm{~cm}$ thick (the spout) to $0.9 \mathrm{~cm}$ thick (the lower parts) were cylindrical with a rounded bottom with the spout diameter of approx. $3.5 \mathrm{~cm}$. Cylindrical crucibles were very popular in the early Middle Ages as more suitable than the older, bowllike forms. According to A. Oldeberg 8 , the height of the Scandinavian specimens amounted to 6-7 cm with a diameter of 5-6 cm. The Poznan forms were slightly smaller, with dimensions similar to the crucibles from Rybitwy near Ostrów Led-

$620 \mathrm{~cm}$ above the poles' negatives was a connecting beam, $1.2 \mathrm{~m}$ long.

7 Z. Goffer, Archaeological chemistry. A sourcebook on the applications of chemistry to archaeology, vol. 55, New York-Chichester-Brisbane-Toronto 1980, pp. 118-119.

8 A. Oldeberg, Metallteknik under vikigatid och medeltid, Stockholm 1966, pp. 79, 256. 
nicki whose walls were from 0.3 to $0.6 \mathrm{~cm}$ thick and the diameter amounted to 3 $\mathrm{cm}^{9}$. The preserved specimens are not complete which makes it difficult to indicate their height; bearing in mind the height-width ratio in the Scandinavian crucibles we could presume that the height amounted to $4 \mathrm{~cm}$. Clay, open cylindrical crucibles of volume amounting to $8 \mathrm{~cm}^{3}$ have also been found in other strongholds and settlements in the Polish territory ${ }^{10}$.

Theophilus Presbyter described in his work the way of producing goldsmith's crucibles: "(...) take white clay and grind it very fine. Then take old pots in which gold or silver has previously been melted and crush them separately. If you do not have these, take pieces of a white earthenware pot and put them on the fire until they are red-hot, and if they do not crack, allow them to cool, and grind them up separately. Then take two parts of ground clay and a third part of the burned pots and mix them with warm water. Knead it well and make crucibles out of it, both large and small ones, in which you will melt gold and silver" ${ }^{11}$. This recipe is confirmed by a piece of an unused crucible from the workshop in question. Its bright-brown, carefully prepared clay mass indicates mineral and ceramic admixtures. In order to firm it, a delicate cloth was used with its imprints on the outer edge of the crucible ${ }^{12}$. Particles of gold on the remaining fragments are evidence of their function: they were used to melt the metal while the glazing on the crucibles' surface corresponds with the temperature in which gold melts i.e. $1062.4^{\circ} \mathrm{C}^{13}$.

In order to melt a small amount of the metal (up to $150 \mathrm{~g}^{14}$ ), one could resort to a cube of charcoal, carved like a bowl. Notably, this form of oak wood $(5.0 \mathrm{~cm}$ long, $4.3 \mathrm{~cm}$ wide and $3.0 \mathrm{~cm}$ high) with a hollow of a diameter of $1.9 \mathrm{~cm}$ and $1.5 \mathrm{~cm}$ deep was found to the north of the remains of the workshop (site Ostrów Tumski 13) in a layer dated back to the $13^{\text {th }}$ century ${ }^{15}$. This layer is attributed to the great

9 D. Banaszak, Pozostałości domniemanej wczesnośredniowiecznej pracowni złotniczej ze stanowiska 12 w Rybitwach, Studia Lednickie 6 (2000), pp. 45-67; cf. p. 48.

10 H. Kóčka-Krenz, Biżuteria pótnocno-zachodnio-słowiańska we wczesnym średniowieczu, Poznań 1993, pp. 19-20.

11 J.G. Hawthorne, C.S. Smith, Theophilus. On Diverse Arts. The Foremost Medieval Treatise on Painting, Glassmaking and Metalwork, New York 1979, p. 96.

12 The analysis was carried out by A. Sikorski from the Faculty of Archaeology of the Adam Mickiewicz University in Poznań.

13 Wielka Encyklopedia Powszechna PWN, vol. 12, Warszawa 1969, p. 728.

14 M. Gradowski, Technika i technologia w dawnym złotnictwie, Warszawa 1975, p. 40.

15 A. Niesiołowska, M. Perzyńska, J. Żak, Badania na posesji Ostrów Tumski 13 w latach 
flood of 1253; possibly, the cube was re-deposited there and had been a part of the workshop's equipment.

In the south-western part of the workshop was a cluster of goldsmith materials; they were small, sometimes of microscopic size. The smallest were particles of sheet and filigree wires. There were also thin plates of melted gold; one with a flat side and another one with an irregular surface indicating that the metal was poured onto a smooth base and its slightly thicker pieces were cut off. Fragments of semi-products have also survived: a wire (?) with failed astragals, a filigree and 4 granules - one of them stuck in the crucible's wall. Special attention should be drawn to parts of the products: a fragment of an ornament with a hammered decoration, an end of a palmette ferrule with two small rivets in it and 3 rivets of similar sizes. The materials suggest that in the Poznań workshop, to major methods were used to process gold: forging and casting coupled with ornamenting techniques in the form of filigree, granulation and striking (pseudo-filigree and pseudo-granulation), sheets were made to cover with gold surfaces made of other materials and ornamental ferrules fixed with rivets to a delicate surface (leather?).

In the workshop, 2 beads and 5 crumbs of gems have also been identified. One of the beads has a cubic-octahedral shape. It is more difficult to identify the type of stone because of a white, non-transparent coat. One of the walls is free of the coating: under a microscope one can see small, milk-white spots against a slightly pink, shiny background. Bearing this in mind one can conclude that it was most probably made of milky quartz whose deposits are in Lower Silesia, the Jizera Mountains and the Tatras ${ }^{16}$. The other, elongated bead has the form of an octagon. It was made of semi-transparent carnelian (a variety of chalcedony), orange-red with brighter colouring. In the ancient times, the stone was excavated in Egypt and Arabia ${ }^{17}$. While in Poland it appears in Lower Silesia and the Świętokrzyskie Mountains ${ }^{18}$ we should presume that the stone was brought to Poznan from abroad. Two small cabochons were turned into cones of purple-red garnets. Garnets come in small clusters in Lower Silesia; the closest main deposits are in Bohemia and Saxony ${ }^{19}$. The remain-

1950-1953, [in:] Poznań we wczesnym średniowieczu, vol. 2, ed. W. Hensel, Wrocław-Warszawa 1960, pp. 67-219, cf. p. 108, footnote. 35, figure 40:20.

16 K. Maślankiewicz, Kamienie szlachetne, Warszawa 1987, p. 201.

17 Ibidem, pp. 203-204.

18 Wielka Encyklopedia Powszechna PWN, vol. 2, Warszawa 1963, p. 375-376.

19 Wielka Encyklopedia Powszechna PWN, vol. 4, Warszawa 1964, p. 382; K. Maślankiewicz, Kamienie szlachetne, p. 189. 
ing specimens are microscopic particles of non-transparent stones coloured blue. Under a microscope one can see spots of pyrite (?) gleaming in the light which is an indication that they are crumbs of lapis lazuli ${ }^{20}$. This supposition is corroborated by identification of ultramarine, a dye obtained from lapis lazuli, on fragments of plaster excavated in the relics of the palace chapel next to the southern wall of St. Mary's Church $^{21}$. Lapis lazuli was used in the early Middle Ages; in Afghanistan it had been excavated for 6000 years $^{22}$ and it is a likely place of origin of the stone brought to Poznań. Finds of these goods allow to take a closer look at the goldsmith techniques applied in the Poznań workshop. Perhaps gems were processed there (milky quartz) into beads or necklaces were made from imported specimens (carnelian). On the other hand, the cabochons clearly indicate that garnets were used to make ornaments by using the cell technique and/or by embedding them in rings ${ }^{23}$.

In the workshop we identified two whole beads and 2 halves; they are all small. One specimen is made of transparent glass in bright green colour ${ }^{24}$, the remaining ones are made of non-transparent yellow glass. They were all made by means of the coiling technique ${ }^{25}$. A similar specimen, $0.5 \mathrm{~cm}$ long and with a diameter of 0.35 $\mathrm{cm}$, was obtained in the course of excavations at 2-4 Wieżowa St., in a layer dated back to the 2 nd half of the $10^{\text {th }}$ century ${ }^{26}$. Earlier excavations in Ostrów Tumski in Poznań failed to provide finds of small, yellow beads made of glass. Glass beads are popular artefacts from the early Middle Ages found in strongholds and settlements and in grave fields ${ }^{27}$. Their chronology encompasses a broad timeframe ranging be-

20 K. Maślankiewicz, Kamienie szlachetne, p. 349, 350.
21 H. Kóčka-Krenz, Posen, vorromanische Kapelle der Fürstenresidenz, [in:] Handbuch zur Geschichte der Kunst in Ostmitteleuropa, Bd. I. 400-1000. Vom spätantiken Erbe zu den Anfängen der Romanik, eds. Ch. Lübke, M. Hardt, Berlin-München 2017, p. 520-521.

22 K. Maślankiewicz, Kamienie szlachetne, p. 224.

23 H. Kóčka-Krenz, Biżuteria pótnocno-zachodnio-stowiańska, pp. 121-124.

24 This type of bead from the $1^{\text {st }}$ half of the $10^{\text {th }}$ century was registered in a glazing workshop in Wolin; it was made of sodium-lead-silicon glass; cf. J. Olczak, Wytwórczość szklarska na terenie Polski we wczesnym średniowieczu. Studia z dziejów rzemiosła i przemystu, vol. 8, Wrocław-Warszawa-Krakow 1968, p. 44.

25 Ibidem.

26 A. Dymaczewski, Badania wykopaliskowe w ogrodzie przy ul. Wieżowej 2-4 w Poznaniu w latach 1939, 1950-1953, [in:] Poznań we wczesnym średniowieczu, ed. W. Hensel, vol. 3, Wrocław-Warszawa 1961, pp. 139-228; cf. pp. 147, 149, table XXVII, figure 2.

27 J. Olczak, E. Jasiewiczowa, Szklarstwo wczesnośredniowiecznego Wolina, Szczecin 1963, p. 43-45. 
tween the $9^{\text {th }}$ century (Gniezno, Ostrów Lednicki) and the $14^{\text {th }}$ century (Gdańsk, Międzyrzecz). Without specialist research and comparative analyses it is difficult to indicate their production place. These beads were made in a glass workshop in Wolin (2nd half of the $10^{\text {th }} \mathrm{c}$. - the 1 st half of the $11^{\text {th }} \mathrm{c}$. $)^{28}$. Finds of glass slags in an alleged workshop in Rybitwy near Ostrów Lednicki lead to a supposition that glass was also processed there ${ }^{29}$. In Ostrów Tumski in Poznań this type of activity has not been identified yet. However, the idea of several specialised workshops including a glass workshop in such an important location could not be altogether rejected. This possibility is corroborated by two pieces of ceramic found in a trench located to the north of St. Mary's Church; they were completely covered in drips of melted glass dyed olive green and red, in a layer dated back to the $11^{\text {th }}$ century ${ }^{30}$. They are direct evidence of local glass processing; use of fragments of ceramic for technological purposes is confirmed in a settlement in Rybitwy near the Lednica stronghold, just to name one example ${ }^{31}$. Hence the conclusion that in the goldsmith workshop necklaces were made from beads which could have been made in the stronghold.

Inside the workshop there were also small particles of bronze artefacts. They have survived in a poor condition, especially the thin, strongly corroded plates which, following excavation, smashed into pieces except for a piece glued to a lump of mortar (?). Of special importance are parts of plates which cling to wood; one of them bears traces of gold-plating. It is difficult to identify the function of a small piece of bronze wire coiled around an axe, most probably production waste. On the other hand, a bronze stud has been well-preserved; its size indicates that it was made to connect a metal ferrule with the wooden base. The resulting objects supplement our knowledge of the scope of the workshop's activities including production of organic objects (wooden boxes?, book covers?), decorated with linings made of bronze as well as gold-plated plates, fixed with delicate little nails.

The relics of the workshop operating in the Poznan stronghold are distinct enough to deduce that the place of work of the goldsmiths followed the recommendations of Theophilus Presbyter who lived in the late $11^{\text {th }}$ and the early $12^{\text {th }}$ centuries and included in his treaty on diverse arts: "Build a high, spacious building

\footnotetext{
28 Ibidem, p. 57.

29 D. Banaszak, Pozostałości domniemanej wczesnośredniowiecznej pracowni, p. 54.

30 H. Kóčka-Krenz, Kostki mozaikowe z Ostrowa Tumskiego w Poznaniu, Archaeologia Historica Polona 15 (2005), 2, pp. 187-200.

31 D. Banaszak, Pozostałości domniemanej wczesnośredniowiecznej pracowni, p. 48.
} 
whose length extends to the east. In the south wall put as many windows as you wish and are able to, provided that there is a space of five feet between any two windows. Then, with a wall rising to the top, divide off half the building for casting operations and for working copper, tin and lead. With another wall divide the remaining half into two parts, one for working gold, the other for silver. The windows should not be more than a foot above ground level and they should be three feet high, two feet wide". He continued as follows: “Then in front of a window, dig a trench, three feet long and two feet wide, a foot and a half from the window wall and at right angles to it. Line the trench all around with wooden boards, of which two in the middle opposite the window should rise half a foot above the trench. On these fasten a table, three feet by two, over the trench to cover the knees of the men sitting in it, and if some small pieces of gold or silver fell on it, could be carefully collected" 32 . These guidelines should be referred to the remains of the workshop in the Poznan stronghold $^{33}$. As the above mentioned materials suggest, gold was the only metal bearing clear traces of local processing. It suggests therefore that the size of the workshop was adjusted to working solely on this metal. The workshop was located in a quadrilateral, wooden structure built on a north-south axis, with a roof supported by three poles, one of them inside the building. This arrangement, slightly straying from Teophilus' recommendations, must have stemmed from the local conditions and allowed to place the windows facing the west and south. In the east, the roof was based on a wall built next to the palas; we know the wall's location by negatives of laths that would suggest the wall's light, frame structure. The remaining walls could have been built by means of formwork as suggested by a strip of russet colouring in the north-west corner. The poles divided the interior into two parts. In the eastern part, the floor (back then on the usable level), was covered with a layer of gypsum mortar. The western part was dredged where the goldsmiths worked, as Theophilus recommended. The area where the finds were gathered suggests a table standing there; all that is left is a negative of a pole and a layer with pieces of charred wood. The distance between the table and the southern wall is in line with Teophilus' description (about $40 \mathrm{~cm}$ ). According to him, the table should have dimensions of 60 $\mathrm{x} 90 \mathrm{~cm}$ which, in turn, is indicated by a layer of ashes. The table was supposed to be placed in a form-worked ditch with the workers' seats on the margins which cor-

\footnotetext{
32 J.G. Hawthorne, C.S. Smith, Theophilus. On Diverse Arts, p. 81.

33 J. Piaskowski, Technologia metali w XI-XII w. w świetle książi Teofila „O sztukach rozmaitych ksiąg troje”, Studia i materiały do dziejów nauki polskiej 3 (1955), pp. 143-178; cf. pp. 147-148.
} 
responds with the difference between the layer of ash and the gypsum floor covering (about $40 \mathrm{~cm}$ ). These observations lead to a conclusion that the workshop was equipped with one work site located in the south-west corner. No kiln or furnace have been identified in the building. However, the crucibles and gold melts indicate unambiguously that the workshop had a source of high temperatures. Hence we should assume that gold was delivered to the workshop in a pure form which did not require refinement; small portions of it were turned into liquid state in crucibles covered in charcoal and placed in a utensil on a table ${ }^{34}$.

Theophilus mentioned the tools that should be in a goldsmith's workshop, namely anvils, hammers, forceps, draw-plates, heading tools, files, chisels, polishing rods, profiles, cutters and crucibles ${ }^{35}$. Only the latter have survived in the Poznań workshop. Notably, gold was also hammered there as confirmed by particles of very thin gold sheets. Gold is a very malleable metal; delicate tools were used to process it, namely anvils/mats and hammers made of organic materials. On the other hand, two pieces of hard wood or a table edge sufficed to draw filigree wires. In order to form granules, a layer of fragmented charcoal or a utensil with water were used ${ }^{36}$. As it has already been stated, the place where the table stood is indicated by a layer of ash. Consequently, the table must have been burnt and the tools made of organic materials must have been completely destroyed.

Specialist research into the stones excavated in the workshop led to important conclusions and shed light on the origin of the goldsmiths employed by the Poznań duke ${ }^{37}$. The research was conducted by means of Raman spectroscopy where five beads of rock crystal were analysed together with five beads of carnelian, two ring stones in the form of carnelian cabochons, a bead made of agate and milky chalcedony. Notably, the objects made of rock crystal have heptagonal outlines. Their shape is reminiscent of a heptagonal faceted bead made of rock crystal excavated in a Lombard grave field in Holubice from the migration period $\left(1^{\text {st }} \text { half of the } 6^{\text {th }} \mathrm{c} \text {. }\right)^{38}$. They also have thicker girdles. These features are evidence that all the beads were processed in a single workshop. Great attention was also attached to processing an

34 Ibidem, pp. 151-152; Figure 8 B.

35 J.G. Hawthorne, C.S. Smith, Theophilus. On Diverse Arts, p. 86.

36 H. Kóčka-Krenz, Biżuteria pótnocno-zachodnio-słowiańska, pp. 17-38.

37 H. Kóčka-Krenz, M. Sachanbiński, J. Skoczylas, R. Girulski, Gemstones from the ducal part of the fortified settlement of Poznan (10 $10^{\text {th }} / 11^{\text {th }}$ century) in the light of gemological studies and micro-Raman spectroscopy, Slavia Antiqua 55 (2014), pp. 145-169.

38 I. Mrázek, Drahé kameny v pravěku Morav a Slezska, Brno 1996, p. 119. 
elongated carnelian bead in the form of an octagonal stud cut on either side by planes perpendicular to its elongation. What is more, there are lateral facets on either side of the stud, combining its walls with the basic dihedron. The agate bead is the least skilfully processed one. Its shape is more oval than in the beads made of rock crystal and its lateral facets are narrower. With the exception of this specific bead, the remaining stones most probably come from workshops enjoying high craft culture combined with a good grinding technique.

The gems from the Poznań goldsmith's workshop have been subjected to comparative studies with specimens of Czech rock crystals and garnets. The results indicate similar features in rock crystals and specimens discovered in pegmatites in Sklené, county Ždár nad Sázavou. As a result, one can state that the rock crystal beads found in the Poznan stronghold were made of quartz excavated in the local deposits. What is more, analyses of the garnet specimens have revealed that they are made of pyrope, a variety of the garnet, as suggested earlier by a macroscope view. Pyropes, also referred to as Czech garnets, stand out for their red colour and have been used in the jewellery trade since the $10^{\text {th }}$ century. All this is evidence that both cabochons from the Poznań workshop come from a source located in the vicinity of Vestřev village near Turnov ${ }^{39}$.

While defining the chronological frames of the workshop's operations, we made reference to its stratigraphic position and the relevant movable sources. The building's floor is on the same level as the then palas. Consequently, a conclusion can be drawn that the workshop was built in the $2^{\text {nd }}$ half of the $10^{\text {th }}$ century, soon after building the stone ducal residence ${ }^{40}$. The materials directly related to the workshop's function do not give grounds for dating the time of its operations. However, an analysis of the ceramics offers such an opportunity. In the workshop, 12 fragments of utensils were identified (technical group II/III) and 919 fragments of completely covered ceramic vessels (GT III) including 56\% of decorated pieces. Judging by the technical and stylistic features, the material can be dated back to the $2^{\text {nd }}$ half of the $10^{\text {th }}$ to the $1^{\text {st }}$ half of the $11^{\text {th }}$ c. (phase $\mathrm{D}_{2}$ ) ${ }^{41}$. The workshop ceased to operate due to a fire which consumed the interior and started in the work area. Fire could have

\footnotetext{
39 V. Bouška, I. Turnovec, Mineralogický symbol Čech - český granát, Turnov 1996.

40 H. Kóčka-Krenz, Początki monumentalnej architektury świeckiej na grodzie poznańskim, [in:] Początki architektury monumentalnej w Polsce, eds. T. Janiak, D. Stryniak, Gniezno 2004, pp. 71-84, cf. p. 82.

41 W. Dzieduszycki, Wczesnomiejska ceramika kruszwicka $w$ okresie od 2 połowy $X$ w. do połowy XIV w., Wrocław-Warszawa-Kraków-Gdańsk-Łódź 1982, pp. 104-106, 109.
} 
been set in the course of heat treatment or during an armed assault. After some time the workshop was covered with a heap of demolition materials, most probably to prop up a corner of the palas reduced by its northern room, possibly as a result of the building's renovation around the mid- $11^{\text {th }}$ century, following Břetislav I's invasion.

The above findings allow to draw important conclusions about Poznań's cultural ties in the early Middle Ages. Back then Poznań was the major stronghold of the first rulers from the Piast dynasty. During the rule of Mieszko I († 992), it was extended into a four-segment complex with the duke's residence separated by an embankment ${ }^{42}$. The ruler's first Christian wife was Doubravka, a Czech princess († 977). Written sources say that she came to Mieszko in 965 with clergymen and magnates accompanying her ${ }^{43}$ and, possibly, servants. The results of the analyses suggest that the entourage could have included a goldsmith who made in the local workshop objects of gold and gems imported from Bohemia for the duchess and her court. One could also venture a hypothesis that Czech gold smithery affected the style of jewellery used in the Piast dominion ${ }^{44}$.

The workshop's equipment which has survived in a very small part, indicates that in the Poznan stronghold and under the ruler's direct supervision, gold was processed into ornaments and luxurious objects (e.g. jewellery boxes) for his family and, predominantly, liturgical equipment, as recommended by Teophilus ${ }^{45}:$ : (...) with all the striving of your mind hasten to complete whatever is still lacking in the house of the Lord and without which the divine mysteries and the administering of the offices cannot continue. These are chalices, candlesticks, censers, cruets, ewers, caskets for holy relics, crosses, missal covers and all the other things that practical necessity requires for use in ecclesiastical ceremony”.

Translated by: Ewa Dratwa

\footnotetext{
42 H. Kóčka-Krenz, On Ostrów Island, nearby which today's Poznań is located..., Poznań 2012.

43 J. Strzelczyk, Mieszko Pierwszy. Chrzest i początki Polski, Poznań 2016, p. 112 et seq.

44 H. Kóčka-Krenz, Biżuteria pótnocno-zachodnio-stowiańska, pp. 155-156, 168.

45 J.G. Hawthorne, C.S. Smith, Theophilus. On Diverse Arts, pp. 79-80.
} 
Prof. dr hab. Hanna Kóčka-Krenz

Wydział Archeologii

Uniwersytet im. Adama Mickiewicza w Poznaniu

ul. Uniwersytetu Poznańskiego 7

61-614 Poznań

e-mail: kockrenz@amu.edu.pl

Nadesłany: 4.01.2020

Nadesłany po poprawkach recenzyjnych: 15.02 .2020

Zaakceptowany: 17.02.2020

\section{Summary}

It discusses the results of specialist analyses of artefacts recovered from a wooden building attached to the north-west corner of a stone residence excavated in the ducal part of an early medieval stronghold in Ostrów Tumski in Poznan. It was found to have housed a goldsmith's workshop from the second half of the tenth century to the first half of the eleventh century. Occupying about $15 \mathrm{~m}^{2}$, the workshop was built according to the instructions contained in the work of Theophilus Presbyter, Diversarum Artium Schedula. Excavations produced fragments of casting crucibles with gold particles (one of them had a golden granule stuck in the wall), fragments of gold foil, filigree, rivets, semi-finished products and finished products, beads of milk quartz, carnelian, rock crystal and two garnet cabochons. Decorative stones from the goldsmith workshop in Poznań were subjected to comparative analyses using the micro-Raman spectroscopy method. Their results showed similarity of rock crystal to specimens found in pegmatites in Sklené, Ždár nad Sázavou District, and the likeness between the garnets and the pyropes (member of the garnet family) from the village of Vestrev near Turnov. This suggests that the beads and cabochons found in the Poznań stronghold were made of raw materials obtained from the deposits to be found there.

In the tenth century, Poznań was among the most important strongholds of Mieszko I. It was the place of residence of Dobrawa, his Christian wife and the Bohemian duchess (d. 977). Written sources report that Dobrawa came to Mieszko in 965 accompanied by the lay and clergy nobility, probably also people in her personal service. The results of the conducted analyses seem to suggest that among them could have been a jeweller, who made items from gold and decorative stones imported from Bohemia for the needs of the Duchess and her court. We can also hypothesise about the influence of Bohemian gold smithery on the style of jewellery that was in use in the Piast state. 


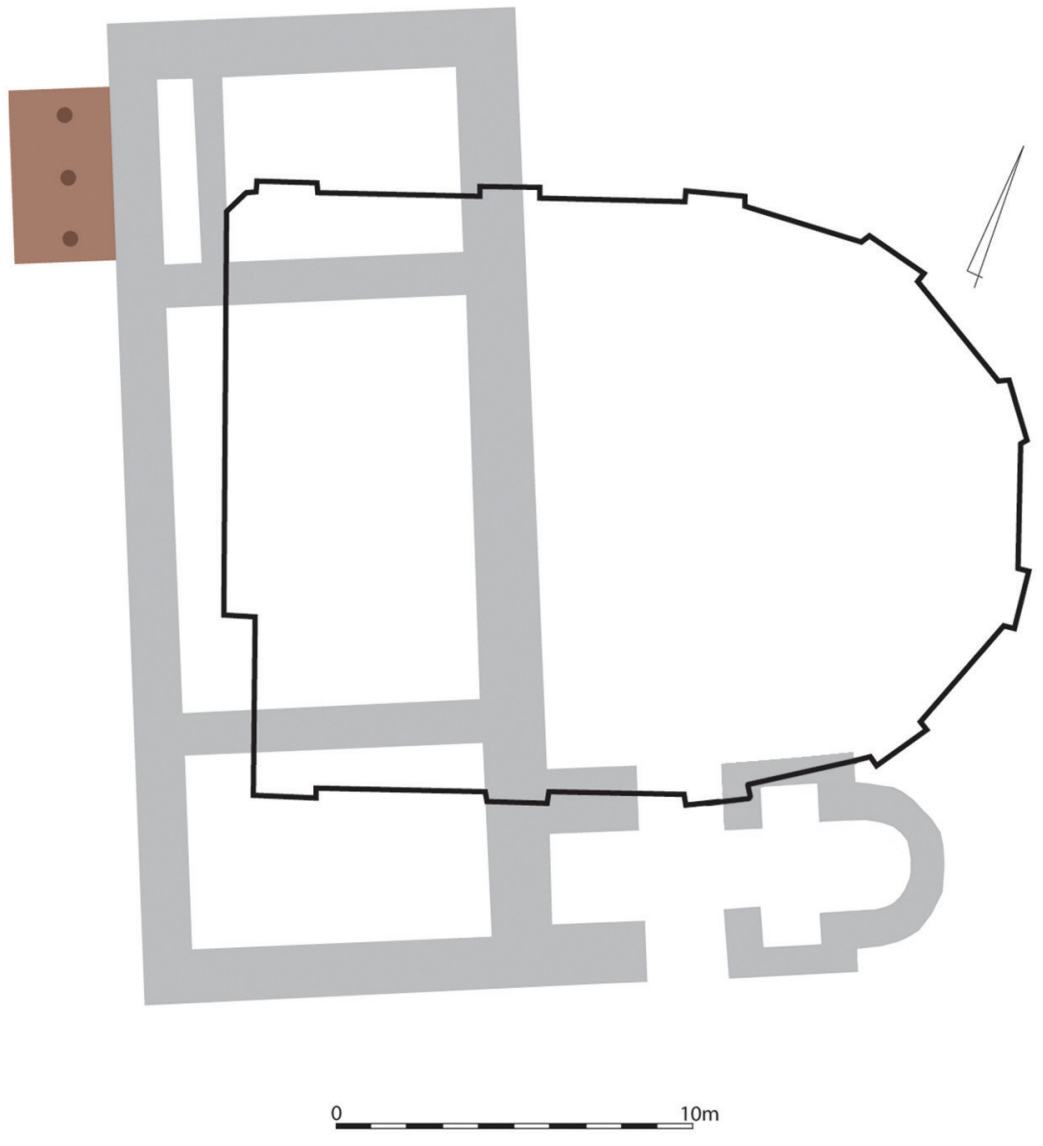

Fig. 1. Poznań-Ostrów Tumski. Palace and sacral complex with goldsmith’s workshop. Drawing by Olga Antowska-Gorączniak.

Ryc. 1. Poznań-Ostrów Tumski. Zespół pałacowo-sakralny z pracownią złotniczą. Rys. Olga Antowska-Gorączniak. 


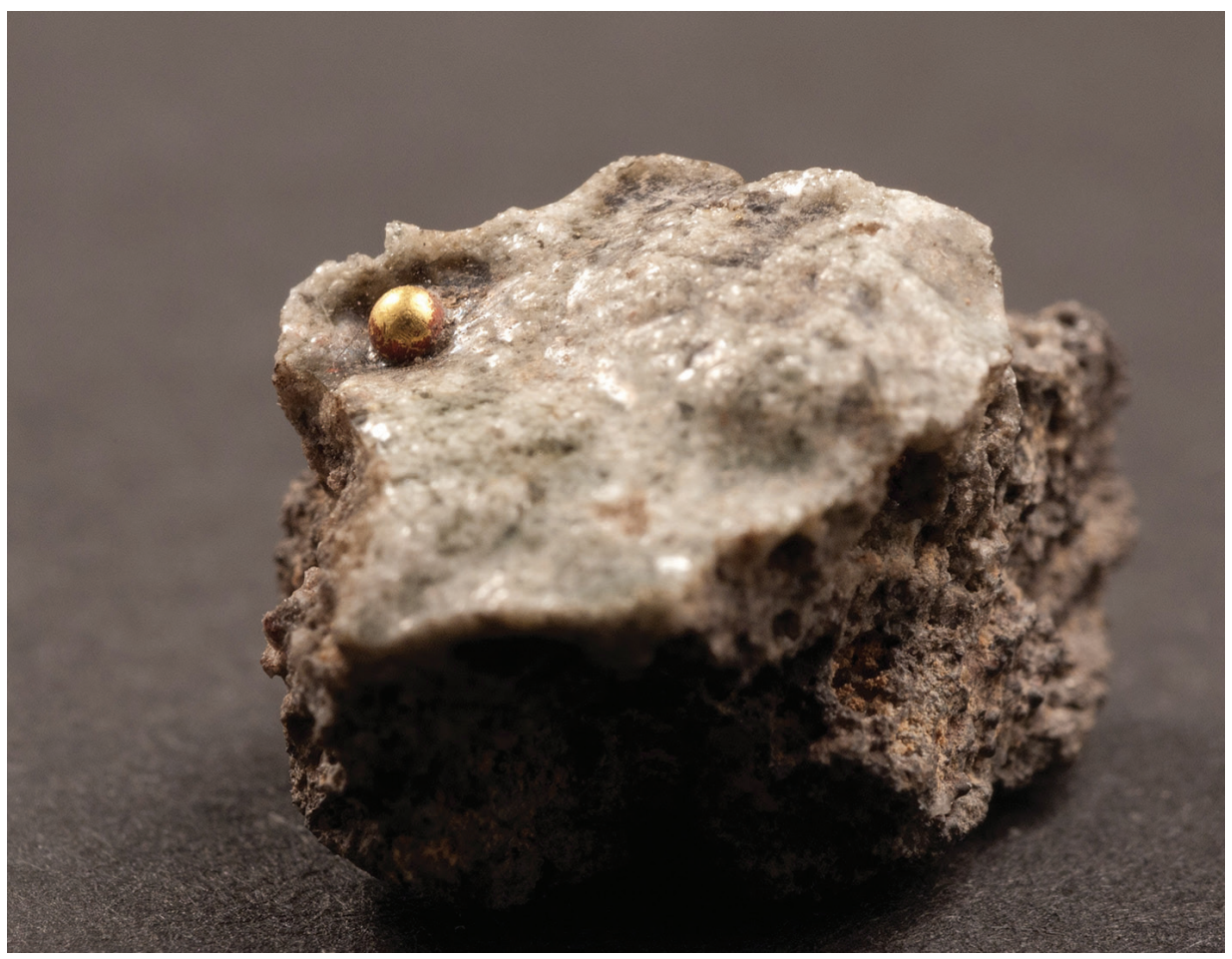

Fig. 2. Poznań-Ostrów Tumski. Fragment of a casting crucible with a gold granule. Photo by Piotr Namiota.

Ryc. 2. Poznań-Ostrów Tumski. Fragment tygielka odlewniczego ze złotą granulką. Fot. Piotr Namiota. 


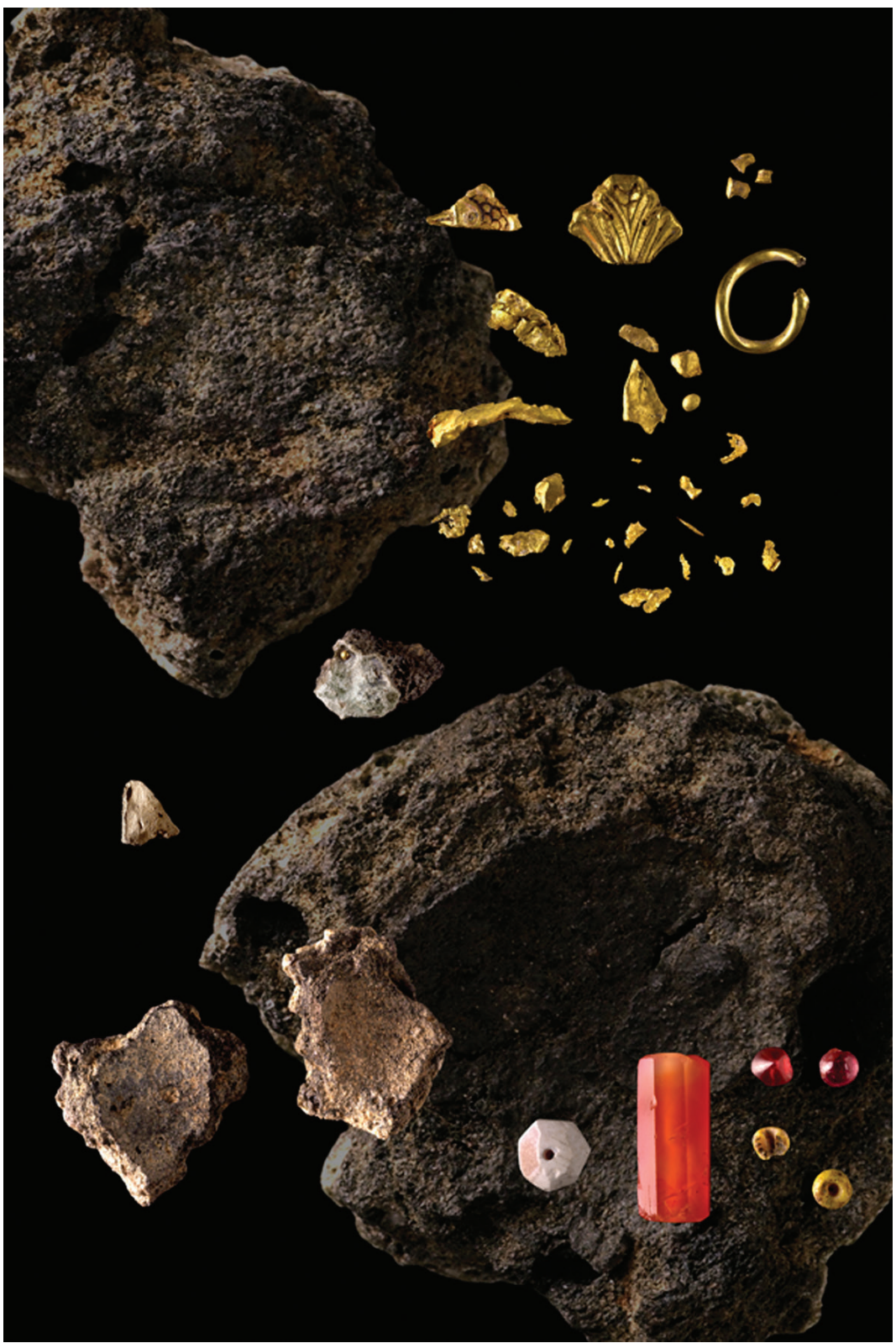

Fig. 3. Poznań-Ostrów Tumski. Fragments of crucibles, artefacts made of gold and decorative stones from the interior of the workshop. Photo by Piotr Namiota.

Ryc. 3. Poznań-Ostrów Tumski. Fragmenty tygielków, wytworów ze złota i kamieni ozdobnych z wnętrza pracowni. Fot. Piotr Namiota. 


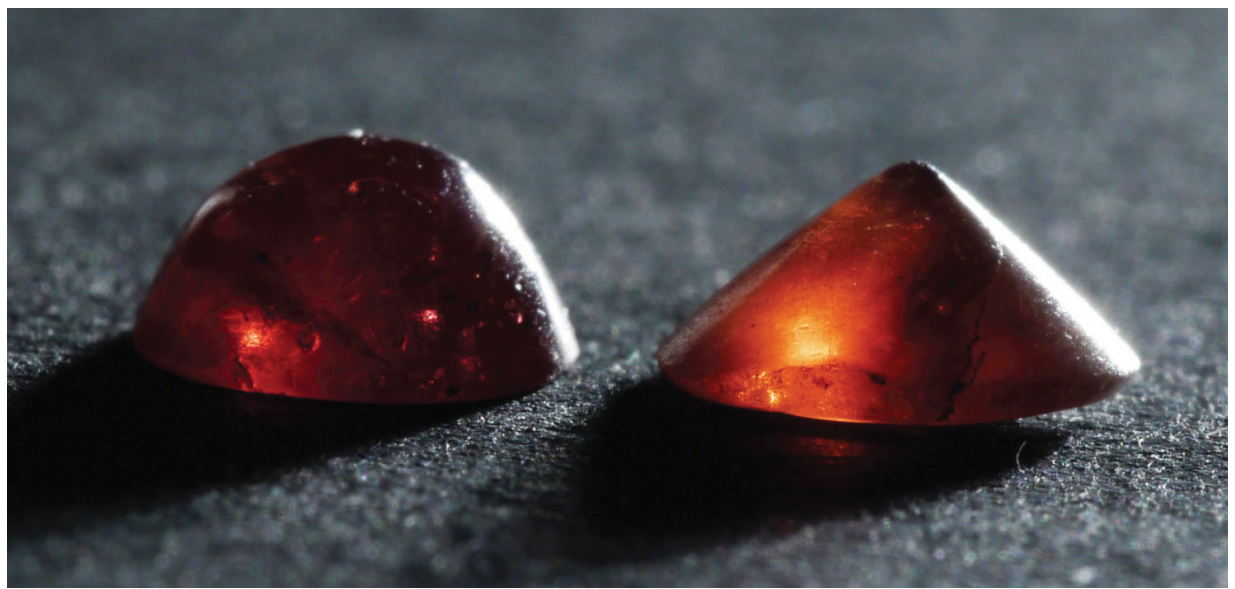

Fig. 4. Poznań-Ostrów Tumski. Garnet cabochons from the goldsmith’s workshop. Photo by Piotr Namiota.

Ryc. 4. Poznań-Ostrów Tumski. Kaboszony z granatów z pracowni złotniczej. Fot. Piotr Namiota.
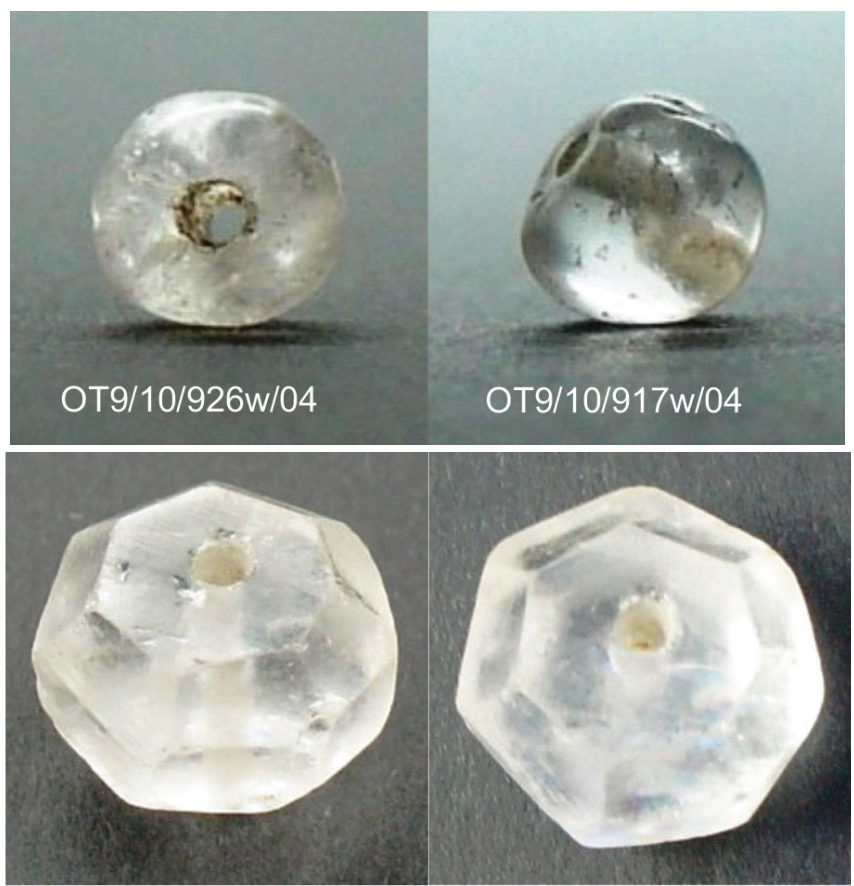

Fig. 5. Poznań-Ostrów Tumski. Rock crystal beads. Fig. Janusz Skoczylas.

Ryc. 5. Poznań-Ostrów Tumski. Paciorki z kryształu górskiego. Fot. Janusz Skoczylas. 

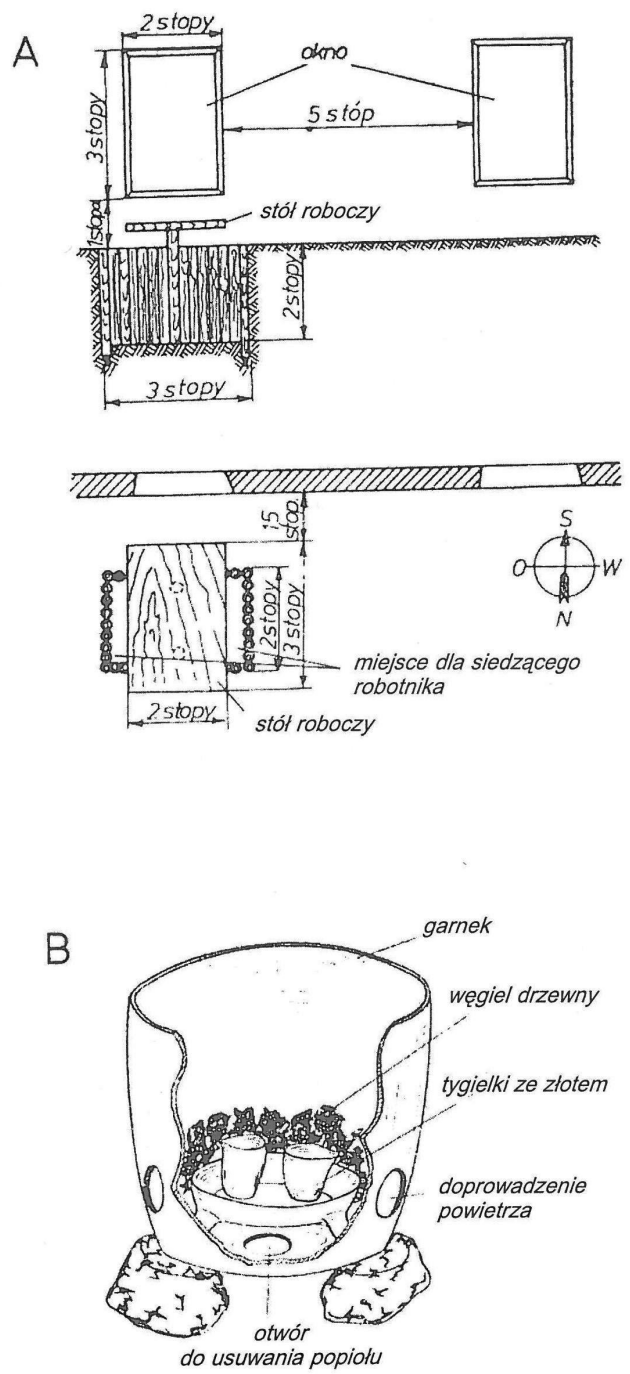

Ryc. 8. A - rekonstrukcja pracowni złotniczej; B - naczynie z tyglami złotniczymi (wg J. Piaskowskiego 1955)

Fig. 6. Reconstruction of the goldsmith's workshop; J. Piaskowski, O sztukach rozmaitych ksiag troje. Technologia metali $w$ XI-XII w. w świetle książki Teofila, Studia i materiały do dziejów nauki polskiej, 3 (1955), ss. 143-178.

Ryc. 6. Rekonstrukcja wyglądu pracowni złotniczej; J. Piaskowski, O sztukach rozmaitych ksiag troje. Technologia metali $w$ XI-XII w. w świetle książki Teofila, Studia i materiały do dziejów nauki polskiej, 3 (1955), pp. 143-178. 


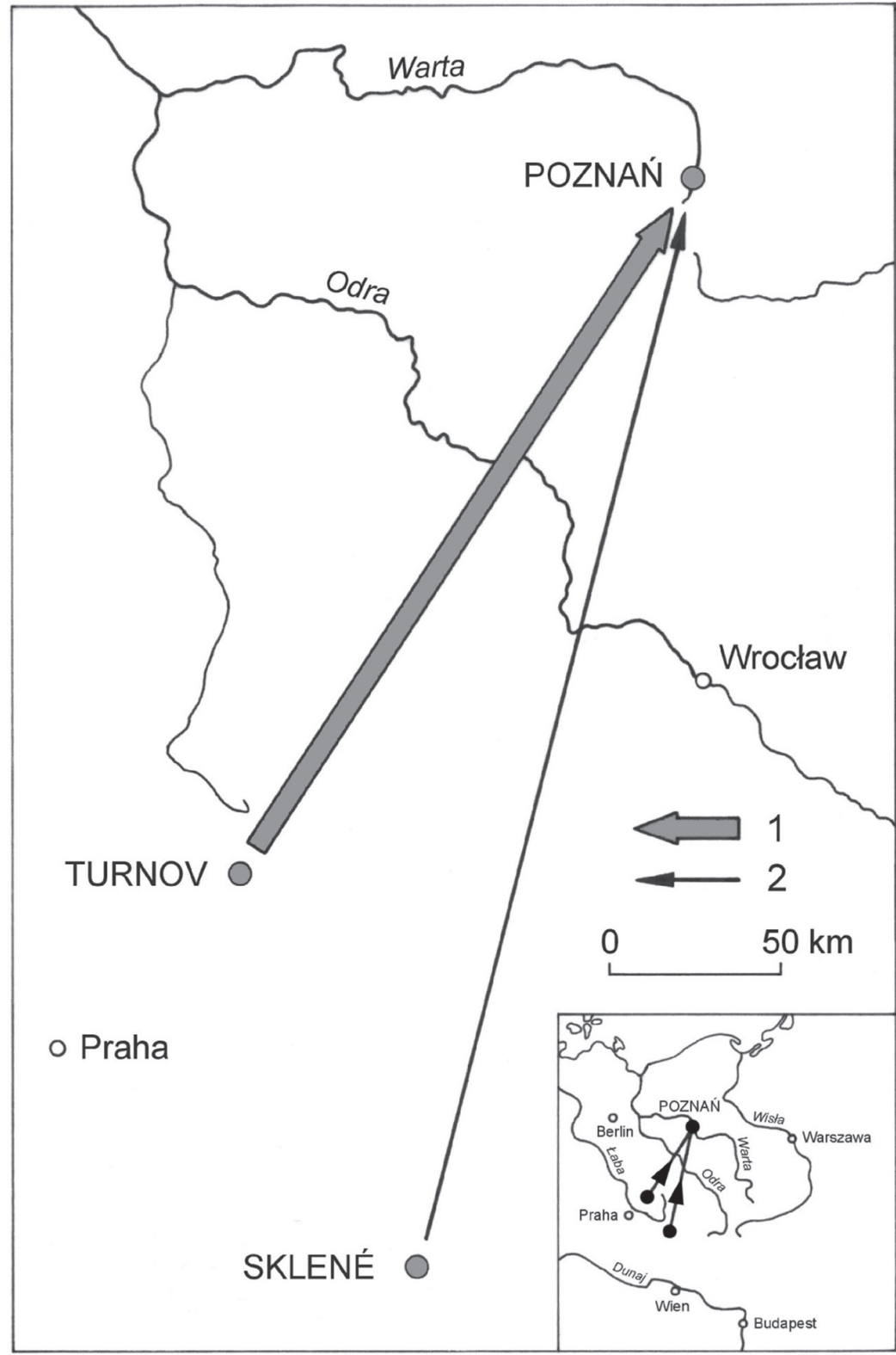

Fig. 7. Origin of garnets and rock crystals from the goldsmith's workshop in Poznań. Photo by Janusz Skoczylas.

Ryc. 7. Pochodzenie granatów i kryształów górskich z poznańskiej pracowni złotniczej. Rys. Janusz Skoczylas. 